\title{
Contribution of Geographic Information Systems in Protection Zones Delineation around a Surface Water Resource in Adzope Region (Southeast of Côte d'Ivoire)*
}

\author{
Serge Kouakou Deh", Kan Jean Kouame, Anowa Evrade Larissa Eba, Jacques Edoukou Djemin, \\ Arsene Kpan, Jean Patrice Jourda
}

Faculty of Earth and Mining Resources Sciences, Laboratory of Water and Environment Sciences and Technology, Abidjan, Côte d'Ivoire

Email: "deh.serge@yahoo.fr

How to cite this paper: Deh, S.K., Kouame, K.J., Eba, A.E.L., Djemin, J.E., Kpan, A. and Jourda, J.P. (2017) Contribution of Geographic Information Systems in Protection Zones Delineation around a Surface Water Resource in Adzope Region (Southeast of Côte d'Ivoire). Journal of Environmental Protection, 8, 1652-1673. https://doi.org/10.4236/jep.2017.813102

Received: October 29, 2017

Accepted: December 26, 2017

Published: December 29, 2017

Copyright $\odot 2017$ by authors and Scientific Research Publishing Inc. This work is licensed under the Creative Commons Attribution International License (CC BY 4.0).

http://creativecommons.org/licenses/by/4.0/

\begin{abstract}
Adzope's Municipal Artificial Lake which serves as a drinking water supply to the population is prone to pollution due to human activities and increasing urbanization. Thus, it is essential to protect this surface water supply for sustainable use. The objective of this study is to determine the protection zones around this water reservoir in order to preserve the stored water quality. To achieve this, a methodological approach based on a Geographic Information System (GIS) was adopted. This methodological approach first consisted to assess the water reservoir vulnerability to pollution according to certain hydrological parameters (slope, land use, soil type, runoff, and drainage network density) and then to determine the protection zones according to the different vulnerability classes. After the scoring of different parameters, a weight was assigned to each, from the multi-criteria method (AHP). The combination of the weighted parameters in the GIS enabled to establish the water reservoir vulnerability indexes map. The vulnerability map established subsequently presents five (5) vulnerability classes in the watershed: very low (12\%) and low $(23 \%)$ in the North and South of the study area, moderate (32\%) disseminated throughout the study area, high (20\%) and very high (13\%) particularly in the West and North of the water reservoir and in the East of study area. This water reservoir vulnerability map is potentially influenced by the land use parameter according to the sensitivity analysis test. The different vulnerability classes then allowed the delimitation of three protection zones (Zone 1, Zone 2 and Zone 3) around the water reservoir. The immediate protection zone (Zone 1) has a width between 100 and $450 \mathrm{~m}$ around the water reservoir with
\end{abstract}

${ }^{*}$ Geographic Information System for protection zones delineation around a surface water resource. 
a surface of $1.16 \mathrm{~km}^{2}$. The delimitation of this immediate protection zone takes into account the high and very high vulnerability classes near the water reservoir. The width of protection zone 2 varies from $350 \mathrm{~m}$ to $1 \mathrm{~km}$ around protection zone 1 with a surface of $5.38 \mathrm{~km}^{2}$. The protection zone 3 covers the rest of the high vulnerability areas contiguous to protection zone 2 with a total surface of $5.69 \mathrm{~km}^{2}$.

\section{Keywords}

GIS, Vulnerability, Protection Zones, Municipal Artificial Lake, Adzope Region

\section{Introduction}

Access to water in sufficient quantity and good quality for populations has always been a challenge to which the scientific community, NGO (Non-Governmental Organization) and governments participate [1]. Declining rainfall due to climate change leads to dwindling water resources in West Africa. Given the diversity and toxicity of pollutant emissions, increasing population and human activities [2], the quality of water resources which are essential to all life's needs, is now threatened. In this situation, the competent Ivorian authorities have taken healthy measures through the elaboration of a water code in 1998. This code requires the establishment of protection areas (Zone 1, Zone 2, and Zone 3) around groundwater wells (drillings) or water storage tank to protect water resources against direct and indirect damages. The procedure for protection zones establishment usually involves three phases [3]. Among these three phases, the technical phase is used to identify places where the surface water resource is exposed to hazards such as pollution related to agricultural, industrial and domestic activities [3]. For this technical phase, the geomatics approach is a suitable technique for identifying areas that are vulnerable to water resources pollution to enable decision-makers to delimit protection zones [4]. Indeed, the population of the study area is supplied with drinking water by a Municipal Artificial Lake or a water storage tank constituted of a dam. This water reservoir is threatened by various types of pollution resulting from human activities taking place in its watershed [5]. The region has wood processing units and has enormous agricultural potential with the production of coffee, cocoa, food and rubber. The human activities taking place in the watershed of this surface water resource generate significant wastes that are likely to degrade the microbiological and physicochemical quality of stored waters. The use of chemical fertilizers and pesticides during agricultural activities can also lead to degradation of the water quality. In addition, there are in the vicinity of this water reservoir, homes in which the wastewater resulting from domestic activities can also promote this degradation. In the face of this threat of water-retention pollution and its consequences for human health, the need to set up protection zones around it from a geomatic approach, becomes indispensable to preserve this resource. This study aims to 
develop a methodology for the application of Geographical Information Systems (GIS) to determine protection zones around this surface water resource. The GIS application methodology is based on multi-criteria analysis (or AHP method) to assess the water reservoir vulnerability to pollution in order to delimit the various protection zones around it as provided in the legislation. GIS are currently presented as the best decision-making techniques by their large mapping capabilities, spatial analysis of natural phenomena and interpretation. They are used to develop comprehensive approaches to water resource management to facilitate the development of solutions to the problem of water quality degradation. GIS are therefore a considerable asset in the search for appropriate water resources management, especially surface water resources.

\section{Presentation of the Study Area}

The study area is at 105 kilometers north of Abidjan's District and is located in the southeast of Côte d'Ivoire. It is in Massan region precisely in the watershed area of Me River. It is between $6^{\circ}$ and $6.10^{\circ}$ North latitudes and $3.5^{\circ}$ and $4^{\circ}$ West longitudes (Figure 1), with an area of 3734 square kilometers. Its population is estimated at about 193,518 inhabitants according to the general population and housing census in 2014 [6]. This zone belongs in a humid climate zone (of Attieen type) that gives a temperature oscillating around $27.5^{\circ} \mathrm{C}$, with an annual rainfall of 1789 millimeters [7]. The study area is characterized by the presence of many hills whose average altitude does not exceed 100 meters and are separated by long valleys to the precipices appearance, from which leave several backwaters and rivers [8]. Concerning hydrography, the study area is traversed by numerous rivers due to abundant rainfall and its relief. The Municipal Artificial Lake of this region (Figure 2) was developed in 1977 on Anvolo stream which is a tributary of Massan River, to satisfy the increasing needs of drinking water of the city's population. This Municipal Artificial Lake of about 2 kilometers long and 500 kilometers wide, occupies an area of 61.44 hectares with a maximum depth of 7 meters [7]. The vegetation is dominated by the humid tropical forest which is constituted of protected forest massifs, as well as secondary forest plots (parcels) and fallow lands that have also favored the establishment of many wood industries [9]. Thus economically, the region depends mainly on agricultural activities and secondarily on a few industrial units specialized in the wood processing installed upstream of the water reservoir. Wastes from these human activities represent potential sources of stored waters pollution intended for human consumption (Figure 3). The soils are ferralitic type moderately leached on schists or mica-schists. Generally the underground of these soils, the regional geological structure is constituted of birrimian schists that pass locally to quartzites, arkoses or graywackes with a schistose tendency [9]. The difficulties of drinking water supply to the population from the contained water in these formations of the bedrock or crystalline plinth are numerous, and that often imposes the choice of surface waters that must be protected against pollutions [10]. 


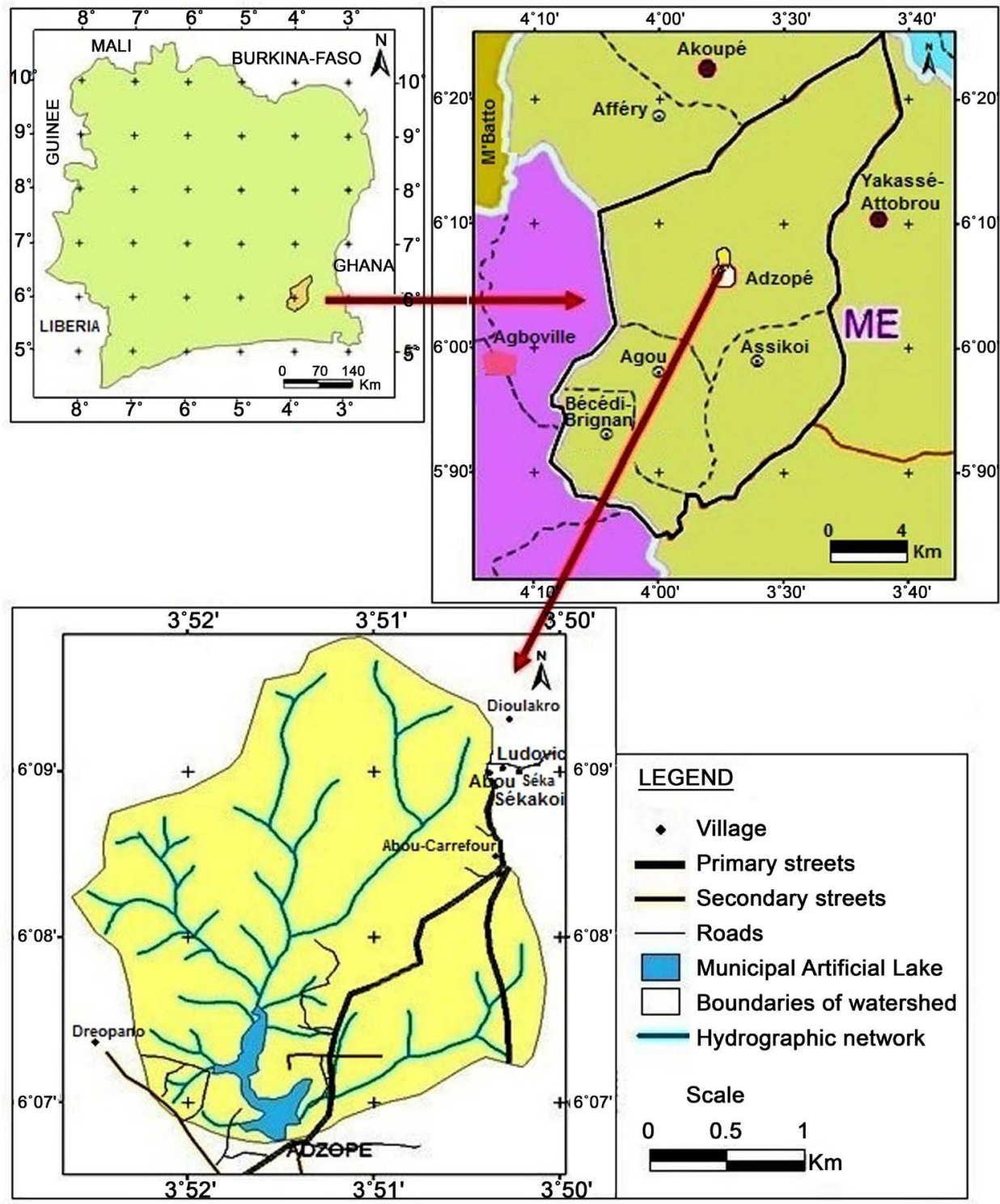

Figure 1. Location of the study area.

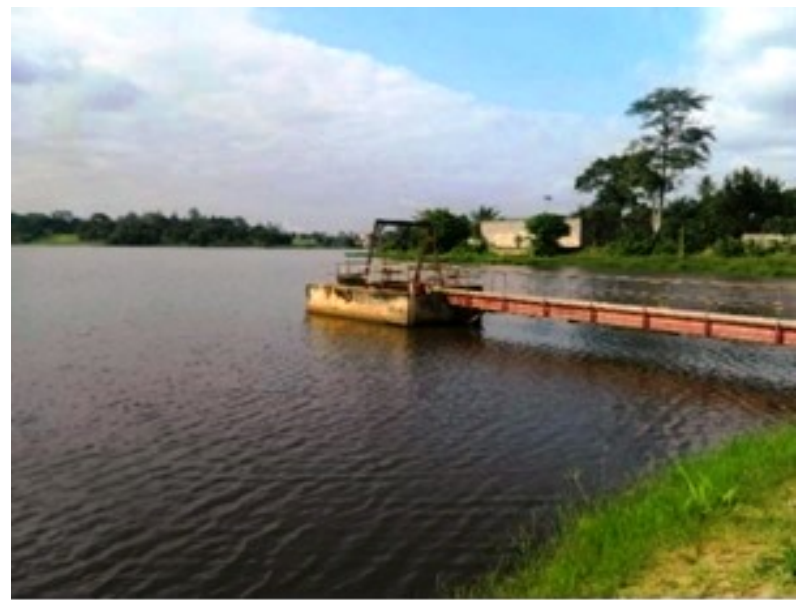

Figure 2. Municipal Artificial Lake or water reservoir of the study area. 

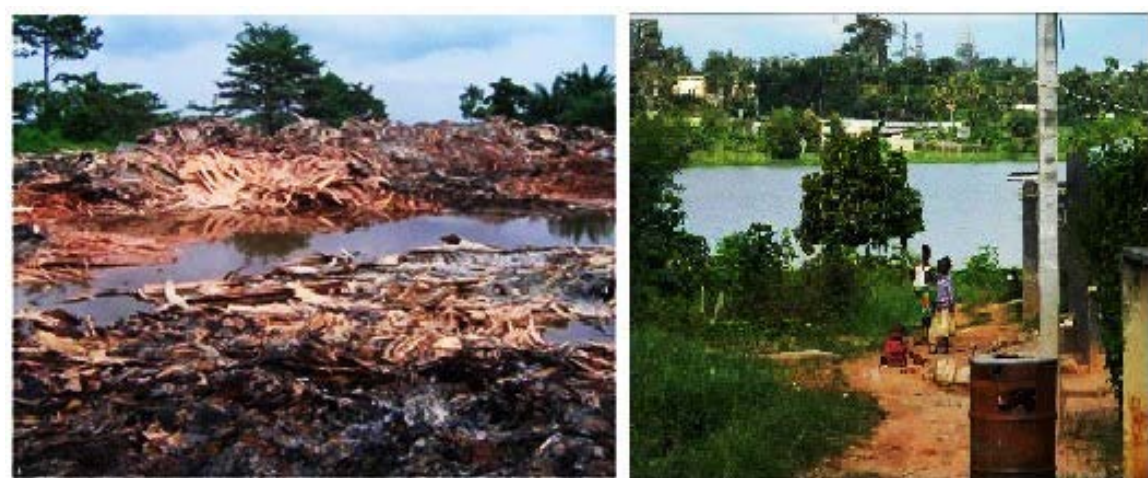

Figure 3. Sources of wastewaters production likely to degrade water quality of Municipal Artificial Lake of the study area.

\section{Material and Methods}

\subsection{Data and Material}

In this study, the portion of land drained by the artificial lake and its tributaries was considered for investigations carried out concerning possible threats of water quality. Indeed, only the identifiable factors on this scale are used [11]. Thus, the contact between the water reservoir and the entire basin is made by surface hydrological phenomena depending on the landscape morphology [12]. Consequently, the mapping of the Artificial Lake vulnerability to pollution has necessitated multi-source data, among which the used cartographic data were composed of:

- the land-use map of the study area established in 2010 at a scale of 1:50,000 by BNETD which is the National Office for Technical and Development Studies;

- the Digital Elevation Model (DEM) of Abidjan-Agboville region [13];

- the soil and geological sketches of Côte d'Ivoire at the scale of 1:2,000,000 established by ORSTOM which is the Office for Scientific and Technical Research of Overseas;

In addition to these cartographic data, there are following data:

- rainfall data from the Adzope station (1975 to 2014);

- monthly average temperatures data measured at the IRHO-Me station (1988 to 2014).

The use of cartographic techniques such as the interpolation and classifications offered by ArcGIS software permitted to develop various thematic layers from these data. Thus, the method to delimit the surface waters protection zones used in this study is that which establishes the protection zones dimensions according to the vulnerability degree of the water reservoir.

\subsection{Methodological Approach}

Surface waters vulnerability to pollution means the ease with which it can be affected by pollution. It depends on the environmental factors that determine the main types of water circulation and land-use [14]. There is no standard method for assessing surface water vulnerability to pollution [11]. Indeed, the methods 
are numerous and most relevant are those that integrate topographic, geological, hydrological and land-use data and ensure a realistic determination of the zones influencing the vulnerability of these resources [15] [16]. Thus, vulnerability assessment accuracy depends essentially on the nature, quantity and reliability of data used. Its characterization is generally based on the estimation of a certain important parameters number [17].

The methodology applied to assess the water reservoir vulnerability to pollution and to determine the protection zones was already used in the previous studies of [15] [16] [18] [19]. Thus, with regard to these works, the methodological approach adopted can be summarized in four steps presented in Table 1.

\subsubsection{Identification, Mapping and Reclassification of Parameters}

The assessment of the vulnerability indexes involves several parameters relating to environmental characteristics, land-use, nature of activities, rejections and soil properties [20]. Thus, five (5) parameters used in the previous studies carried out by [11] [18] [19] in Côte d'Ivoire respectively in Taabo, Gagnoa and Abidjan regions were retained. It is about the Slope (Sl), Land-use (Lu), Soil media (S), Runoff (R) and drainage network Density (D). Ratings assignment to the different classes of identified parameters was based on the previous studies of [15] on Surface Water vulnerability assessment. The ratings vary from 1 to 4 and were assigned according to the importance of the different classes in the process of phenomenon studied. Thus, Table 2 summarizes parameters, different classes and the assigned ratings to these classes.

Slope (Sl)

Slope is the essential parameter in the pollutants transfer to surface waters. It was generated after the application of a mask to the DEM of Abidjan-Agboville zone to obtain the DEM of the study area. From this DEM, slope parameter (Sl)

Table 1. Summary of the steps in the methodological approach.

\begin{tabular}{|c|c|c|}
\hline Steps & Methods & Processes \\
\hline \multirow{3}{*}{1} & Identification of parameters & $\begin{array}{l}\text { Choice of used parameters to calculate the pollution } \\
\text { vulnerability index }\end{array}$ \\
\hline & Thematic mapping & $\begin{array}{l}\text { - mapping each parameter at the scale of the studied } \\
\text { watershed } \\
\text { - discretization of each parametric map (Cell size }=20 \times \\
20 \mathrm{~m} \text { ) }\end{array}$ \\
\hline & $\begin{array}{l}\text { Reclassification of } \\
\text { parameters }\end{array}$ & $\begin{array}{l}\text { Each parameter is subdivided into } 3 \text { or } 4 \text { classes } \\
\text { according to the ratings or weights assigned }\end{array}$ \\
\hline 2 & Weighting of parameters & $\begin{array}{l}\text { Prioritize the parameters relative to each other by Saaty } \\
\text { method }\end{array}$ \\
\hline 3 & Vulnerability assessment & $\begin{array}{l}\text { Combination of the different thematic maps by } \\
\text { weighting to obtain a final map of the vulnerability } \\
\text { index distribution }\end{array}$ \\
\hline 4 & $\begin{array}{l}\text { Determination of protection } \\
\text { perimeters or zones }\end{array}$ & $\begin{array}{l}\text { Delimitation of protection perimeters or zones (Zone 1, } \\
\text { Zone } 2 \text { and Zone } 3 \text { ) according to the vulnerability map }\end{array}$ \\
\hline
\end{tabular}


Table 2. Parameters, classes and attributed ratings to the different parameters [15].

\begin{tabular}{|c|c|c|}
\hline Parameters & Classes & Ratings \\
\hline \multirow{3}{*}{ Slope (Sl) (\%) } & $<3$ & 1 \\
\hline & $3-7$ & 2 \\
\hline & $>7$ & 3 \\
\hline \multirow{5}{*}{ Land-use (Lu) } & Dense forest & 1 \\
\hline & Woodland (open forest) & 1 \\
\hline & Habitats & 2 \\
\hline & Bare Ground & 3 \\
\hline & Cultivations (crops) and fallow & 4 \\
\hline \multirow{3}{*}{ Soil media (S) } & Soil ferralitic strongly desaturated & 1 \\
\hline & Soil ferralitic moderately desaturated & 2 \\
\hline & Hydromorphic soil & 3 \\
\hline \multirow{3}{*}{ Runoff (R) (mm) } & $<0$ & 1 \\
\hline & $0-150$ & 2 \\
\hline & $>150$ & 3 \\
\hline \multirow{3}{*}{$\begin{array}{c}\text { Drainage Network } \\
\text { Density (D) }\left(\mathrm{km} / \mathrm{km}^{2}\right)\end{array}$} & $<1.04$ & 1 \\
\hline & $1.04-1.33$ & 2 \\
\hline & $>1.33$ & 3 \\
\hline
\end{tabular}

was mapped using ArcGis "Slope" tool. A reclassification of slopes map was then carried out using ratings given by [15] (Table 2) to obtain the reclassified slopes map. The obtained slopes classes reflect a strong dominance of average slopes throughout the watershed of the study area. These classes correspond to slopes between $3 \%$ and $7 \%$.

Land use $(\mathrm{Lu})$

Land-use contains potential sources of water reservoirs pollution. It also plays an important role in the rainwater runoff, retention of suspended solids and pollutants absorption [21]. The land-use map of the studied watershed was obtained by digitizing the portions of the different types of occupancy identified on the land-use map established by BNETD in 2010. A reclassification of this landuse was made into account the ratings in Table 2. This map presents three classes on the entire watershed: classes 1,2 and 4. Crops and fallow lands represent the dominant class. It is located north of the artificial lake and at the watershed eastern limit. It reflects a high water reservoir pollution risk due to the use of agricultural inputs in these areas.

Soil media (S)

This parameter corresponds approximately to the first meter of deposition from soil surface [22]. According to [21], soil permeability and bedrock plays a role on the rainwaters part which participates in runoff but also on transit times to the hydrographic network. Analysis of the soil sketch of Côte d'Ivoire at the 1:2,000,000 scale shows that the water reservoir watershed contains only mod- 
erately leached ferralitic soils [23]. Then the rating " 2 " has been assigned to parameter "S".

Annual Runoff (R)

Runoff is one of erosion factors. The water that flows with it carries particles that are more or less large depending on water amount in motion and slope [24]. Thus, natural water quality results from the mineralization processes that occur during water runoff on the soil [25]. The annual runoff determination was based on a calculation which takes into account the rainfall of the area over forty years (1975 to 2014). Indeed, annual runoff is closely linked to the rain amount that has fallen and infiltrated. Runoff assessment is based on "Equation (1) from the Thornthwaite method":

$$
R=r \times P
$$

where, $R$ is runoff (mm), $r$ is runoff coefficient (\%) and $P$ is total annual rainfall $(\mathrm{mm})$.

In this study, rainfall data such as total annual rainfall $(\mathrm{mm}) \mathrm{P}=1391 \mathrm{~mm}$ and the runoff coefficient of $13 \%$ determined by [9] on the Me watershed were used. Thus, from the hydrological balance, we have: $\mathrm{R}=13 \% \times 1391 \mathrm{~mm}=$ $180.83 \mathrm{~mm}$. So the rating " 3 " was assigned to the parameter " $\mathrm{R}$ " according to the classification to [15].

Drainage Network Density (D)

Drainage network Density is defined as the total length of the hydrographic network per unit area of watershed. Pollution of surface water resources (lakes, stream, rivers...) is also linked to hydrographic network density that underlies these resources [15]. Drainage network Density mapping was performed by digitizing of watershed hydrographic network obtained from the land-use map. This parameter is evaluated on the basis of a regular mesh of the space through "Line density" tool in "Spatial analysis" of ArcGis. Three drainage network Density classes were then defined from Table 2 to obtain the reclassified drainage network Density map.

\subsubsection{Weights Determination by AHP Method}

The method used to determine parameter weights is the AHP (Analytic Hierarchy Process) multi-criteria analysis developed by Saaty. Thus, the approach adopted by this method can be summarized in three main steps:

- the development of the hierarchy;

- the elaboration of binary combinations;

- The verification of logical consistency and determination of parameters weights.

- Development of the hierarchy

To develop the hierarchy, the method simplifies the problem to be resolved according to a hierarchical structure, and then gives relative importance to each element of each level [26]. The elaborated parameters above were grouped into a homogeneous set and arranged in different levels (Figure 4). The different levels 
of AHP method in this study following Saaty [27] are:

- level 0 corresponds to the mapping of water reservoir vulnerability to pollution;

- level 1 regroups all the identified parameters above.

The parameters chosen are five and the established hierarchy structure is illustrated in Figure 4.

- Elaboration of binary combinations

For elaboration of the binary combinations, the parameters are compared two by two (pairwise comparison) according to their importance. This comparison is based on the Saaty's scale or Saaty's pairwise comparison. Indeed, when two parameters have the same importance in the studied phenomenon, Saaty's scale attributes the value " 1 " to these parameters. However, if one parameter is more important than the other, then it takes a higher value between 1 and 10, and the other takes the inverse of this value. Example: the comparison of the slope (moderately important) with the soil media (moderately less important) concerning the studied phenomenon in this study, the values " 3 " and " $1 / 3$ " were respectively assigned for the slope and the soil media. These comparisons lead to development of a reciprocal square matrix (Table 3 ). This method produces standardized weighting coefficients with their sum equal to 1 .

- Verification of logical consistency or consistency ratio (RC) of the matrix

This operation does not require that judgments be coherent or transitive, but [26] has defined a consistency index (IC) according to "Equation (2)". Thus, the consistency ratio $(\mathrm{RC})$ is determined from the calculated consistency index on matrix by the random consistency index (IA) of a matrix of the same size. The

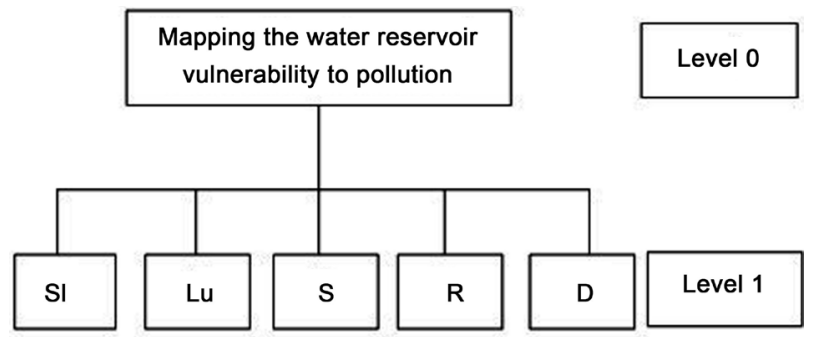

Figure 4. Hierarchical structure of the problem to be resolved.

Table 3. Pairwise comparison matrix of the various parameters (original matrix).

\begin{tabular}{cccccc}
\hline & $\mathrm{Sl}$ & $\mathrm{Lu}$ & $\mathrm{S}$ & $\mathrm{R}$ & $\mathrm{D}$ \\
\hline $\mathrm{Sl}$ & 1 & 2 & 3 & 5 & 6 \\
$\mathrm{Lu}$ & $1 / 2$ & 1 & 2 & 3 & 5 \\
$\mathrm{~S}$ & $1 / 3$ & $1 / 2$ & 1 & 2 & 3 \\
$\mathrm{R}$ & $1 / 5$ & $1 / 3$ & $1 / 2$ & 1 & 1 \\
$\mathrm{D}$ & $1 / 6$ & $1 / 5$ & $1 / 3$ & $1 / 2$ & 17 \\
$\mathrm{Nai}$ & 2.20 & 4.03 & 6.80 & 11.5 & 17 \\
\hline
\end{tabular}

Sl: Slope, Lu: Land-use, S: Soil media, R: Runoff, D: drainage network Density, aai: Sum of the values. 
consistency ratio is a comparison between consistency index and random consistency index [28]. This consistency ratio makes allows to check or validate the original matrix consistency. If the consistency ratio is greater than 0.1 (or 10\%) the subjective judgment should be revised in the original matrix. But, if the value of consistency ratio is smaller or equal to $10 \%$, the inconsistency is acceptable. The consistency ratio is determined according to "Equation (3)". The random consistency index (AI) values are given according to the number of used criteria. These values were determined by Saaty (Table 4 ). In this study, five parameters were used. The value of IA therefore corresponds to 1.12.

$$
\begin{gathered}
I C=\left(\lambda_{\max }-k\right) /(k-1) \\
R C=I C / I A
\end{gathered}
$$

where, $K$ is the number of compared elements, $\lambda_{\max }$ is the maximum eigenvalue of compared elements, $I C$ is consistency index, $A I$ is random consistency index and $\mathrm{RC}$ is consistency ratio.

- Determination of weighting coefficients $(\mathrm{Cp})$

The weighting coefficient $(\mathrm{Cp})$ of a parameter can be defined in this study as the intensity of its influence in assessment of water reservoir vulnerability to pollution. Its determination is made through the eigenvectors calculation $(\mathrm{Vp})$, from "Equation (4)". The weighting coefficients are determined from "Equation (5)". The weighting coefficients sum of all the parameters of a matrix must be equal to 1 . All the results of the different calculations are given in Table 5. In this table, the "slope" parameter has a greater weight (0.44). It will therefore largely influence the water reservoir vulnerability to pollution. The land-use parameter (with a weight of 0.27 ) will also influence this vulnerability assessment. The consistency ratio value obtained after the calculations is less than $10 \%(\mathrm{RC}=$ $2.01 \%)$. Therefore the judgments attributed to the parameters can be considered satisfactory.

$$
V p=\sqrt[k]{W_{1} \times \cdots \times W_{k}}
$$

Table 4. Random indexes of a matrix of the same dimension [26].

\begin{tabular}{|c|c|c|c|c|c|c|c|c|c|c|c|c|c|c|}
\hline & $\mathrm{Sl}$ & $\mathrm{Lu}$ & $S$ & $\mathrm{R}$ & $\mathrm{D}$ & $\mathrm{Bi}$ & $\mathrm{Mi}$ & $\mathrm{Gi}$ & $\mathrm{Ei}$ & $\lambda_{\max }$ & IC & $\mathrm{RC}$ & $\mathrm{Vp}$ & $\mathrm{Cp}$ \\
\hline $\mathrm{Sl}$ & 0.45 & 0.50 & 0.44 & 0.43 & 0.35 & 2.18 & 0.44 & 2.22 & 5.097 & \multirow{6}{*}{5.09} & \multirow{6}{*}{0.} & \multirow{6}{*}{0.0201} & 2.83 & 0.44 \\
\hline $\mathrm{Lu}$ & 0.23 & 0.25 & 0.29 & 0.26 & 0.29 & 1.32 & 0.26 & 1.35 & 5.101 & & & & 1.72 & 0.27 \\
\hline S & 0.15 & 0.12 & 0.15 & 0.17 & 0.18 & 0.77 & 0.15 & 0.79 & 5.092 & & & & 1.00 & 0.15 \\
\hline $\mathrm{R}$ & 0.09 & 0.08 & 0.07 & 0.09 & 0.12 & 0.45 & 0.09 & 0.46 & 5.091 & & & & 0.58 & 0.09 \\
\hline $\mathrm{D}$ & 0.08 & 0.05 & 0.05 & 0.04 & 0.06 & 0.28 & 0.06 & 0.28 & 5.069 & & & & 0.35 & 0.05 \\
\hline$\sum$ & 1.00 & 1.00 & 1.00 & 1.00 & 1.00 & 5.00 & 1.00 & 5.10 & 25.451 & & & & 6.48 & 1.00 \\
\hline
\end{tabular}

\begin{tabular}{ccccccccccc}
\hline Criteria number & 2 & 3 & 4 & 5 & 6 & 7 & 8 & 9 & 10 & 11 \\
\hline IA & 0.00 & 0.58 & 0.90 & 1.12 & 1.24 & 1.32 & 1.41 & 1.45 & 1.49 & 1.51 \\
\hline
\end{tabular}

Table 5. Results of the different calculations of matrix. 
where, $V p$ is eigenvector of parameter, $W_{k}$ is main note assigned to the parameter, $\mathrm{k}$ is number of parameter. Example: Calculation of $V p$ of the slope parameter: $V p=\sqrt[5]{1 \times 2 \times 3 \times 5 \times 6}=2.83$.

$$
C p=V p /(V p+\cdots+V p k)
$$

where, $V p$ is eigenvector of parameter, $V p k$ represents the different eigenvectors of the parameters and $\mathrm{Cp}$ is weighting coefficient. Example: Calculation of $C P$ of the slope parameter: $C p=2.83 / 6.48=0.44$.

\subsubsection{Assessment of Municipal Artificial Lake Vulnerability}

The approach used to assess the water reservoir vulnerability to pollution in the study area was the weighted sum of the various parameters to obtain vulnerability index map where the indexes vary between 0 and 10 . The calculation of the global vulnerability index (IVg) was performed according to "Equation (6)":

$$
I V g=\sum_{i=1}^{i=n} C_{p i} \times R i
$$

where, $I V g$ is global vulnerability index, $C p i$ is weighting coefficient of parameter $i, R i$ is class of parameter $i$ and $n$ is number of parameters. In this study, the application of the general Equation (6) makes it possible to obtain the following "Equation (7)":

$$
I V g=0.44 \times S l+0.27 \times L u+0.15 \times S+0.09 \times R+0.05 \times D
$$

These indexes represent a measure of the degree of the water reservoir contamination risk through the various stresses of its watershed. Finally, a classification of the vulnerability index map according to Table 6 is made to obtain the water reservoir vulnerability map. Thus, vulnerability is more important when the calculated index is high. To determine the intervals of various vulnerability indexes, "equation (8) established by the Ministry of Agriculture, Fisheries and Food of Quebec" [29], was used to perform the conversion of vulnerability indexes in percentage (Table 6). This conversion made it possible to better understand the classification expression of vulnerability degrees.

$$
\operatorname{IVg}(\%)=\left(\left(V g_{i}-V g_{\text {Min }}\right) /\left(V g_{\text {Max }}-V g_{\text {min }}\right)\right) \times 100
$$

where, $I V g_{i}$ is vulnerability index to be identified.

\subsubsection{Sensitivity Analysis of Vulnerability Map: Single-Parameter Sensitivity Analysis Test}

A sensitivity analysis was conducted to assess the effect of each parameter

Table 6. Indexes and degrees of vulnerability [30].

\begin{tabular}{ccc}
\hline Classes of vulnerability indexes & Index intervals & Degrees of vulnerability \\
\hline $1.48-2.017$ & $0 \%-30 \%$ & Very low \\
$2.03-2.28$ & $31 \%-45 \%$ & Low \\
$2.30-2.55$ & $46 \%-60 \%$ & Moderate \\
$2.57-2.82$ & $61 \%-75 \%$ & High \\
$2.84-3.27$ & $76 \%-100 \%$ & Very high \\
\hline
\end{tabular}


selected in multi-criteria analysis for mapping of the water reservoir vulnerability to pollution. For this purpose, single parameter sensitivity analysis test developed by [31] was used. This test allows was used to analyze the actual influence of the weighting in relation to the assigned weights to each parameter in multicriteria analysis. In this analysis, the actual weight was compared to that provided by multi-criteria analysis (theoretical weights). The effective weight (W) of each parameter was calculated from "Equation (9)":

$$
W(\%)=((X r \times X w) / V) \times 100
$$

where, $X r$ and $X_{W}$ are respectively the rating and weight assigned to the parameter $X$, and $V$ is the vulnerability index to pollution according to multi-criteria analysis method.

\subsubsection{Protection Zones Delineation of Municipal Artificial Lake}

In this study, the protection zones delineation integrates the water reservoir vulnerability map, the recommendations of some previous studies [18] [19] [32] and the national legislation in force [33]. This legislation recommends three protection perimeters or zones (Zone 1, Zone 2, and Zone 3) around water resources. For wellhead protection perimeters or zones, the Zone 1 is characterized of accident prevention zone or sanitary protection zone, Zone 2 is attenuation zone, and Zone 3 is remedial action zone.

- Immediate protection zone delineation (Zone 1)

The immediate protection zone (Zone 1 ) is determined by taking into account the very high, high, medium and low vulnerability classes around the water reservoir. This determination was also performed according to several previous studies (Table 7). Thus, a radius of $100 \mathrm{~m}$ was considered to delimit immediate protection zone where the contamination risk is very important because of the lower dilution potential and the low transit time of the contaminants to the water reservoir. This radius was increased (greater than $100 \mathrm{~m}$ ) for most vulnerable areas adjacent or contiguous to the water reservoir.

- Protection zone 2 delineation (Zone 2)

The protection zone 2 must protect the water reservoir effectively from the direct migration of pollutants. It can be defined as an area arbitrarily used or a predefined distance which provides for a sufficient time to intervene in the event

Table 7. Radius of immediate protection zones in various studies.

\begin{tabular}{cccc}
\hline References & Countries & Types of water intake & Radius of Zone 1 \\
\hline$[32]$ & Quebec & Lake and River & 300 to $1000 \mathrm{~m}$ \\
{$[19]$} & Côte d'Ivoire & River & 200 to $500 \mathrm{~m}$ \\
{$[16]$} & Maroc & Lake & $100 \mathrm{~m}$ \\
{$[34]$} & Maroc & Lake & $100 \mathrm{~m}$ \\
{$[35]$} & France & Lake & $100 \mathrm{~m}$ \\
\hline
\end{tabular}


of point-source pollution [32]. The limits of this zone correspond to an equivalent distance to a necessary time for the complete elimination of any contamination by natural attenuation. Its extent is determined in this study by taking into account several factors such as physical characteristics (slope), water flow direction and high vulnerability areas from the boundaries of protection zone 1 .

- Protection zone 3 delineation (Zone 3)

The protection zone 3 protects water resources against mobile and persistent pollutants (hydrocarbons, pesticides ...) [16]. It generally concerns the entire area of watershed located upstream where the pollution risks are obvious [34]. Thus, protection zone 3 was established by considering the high and very high vulnerability areas from the boundaries of protection zone 2 .

\section{Results and Discussion}

\subsection{Results}

- Municipal Artificial Lake vulnerability map

The water reservoir vulnerability map obtained from the compilation of thematic maps reveals five vulnerability classes (very low, low, moderate, high and very high) (Figure 5). The very low vulnerability class (12\%) is generally located

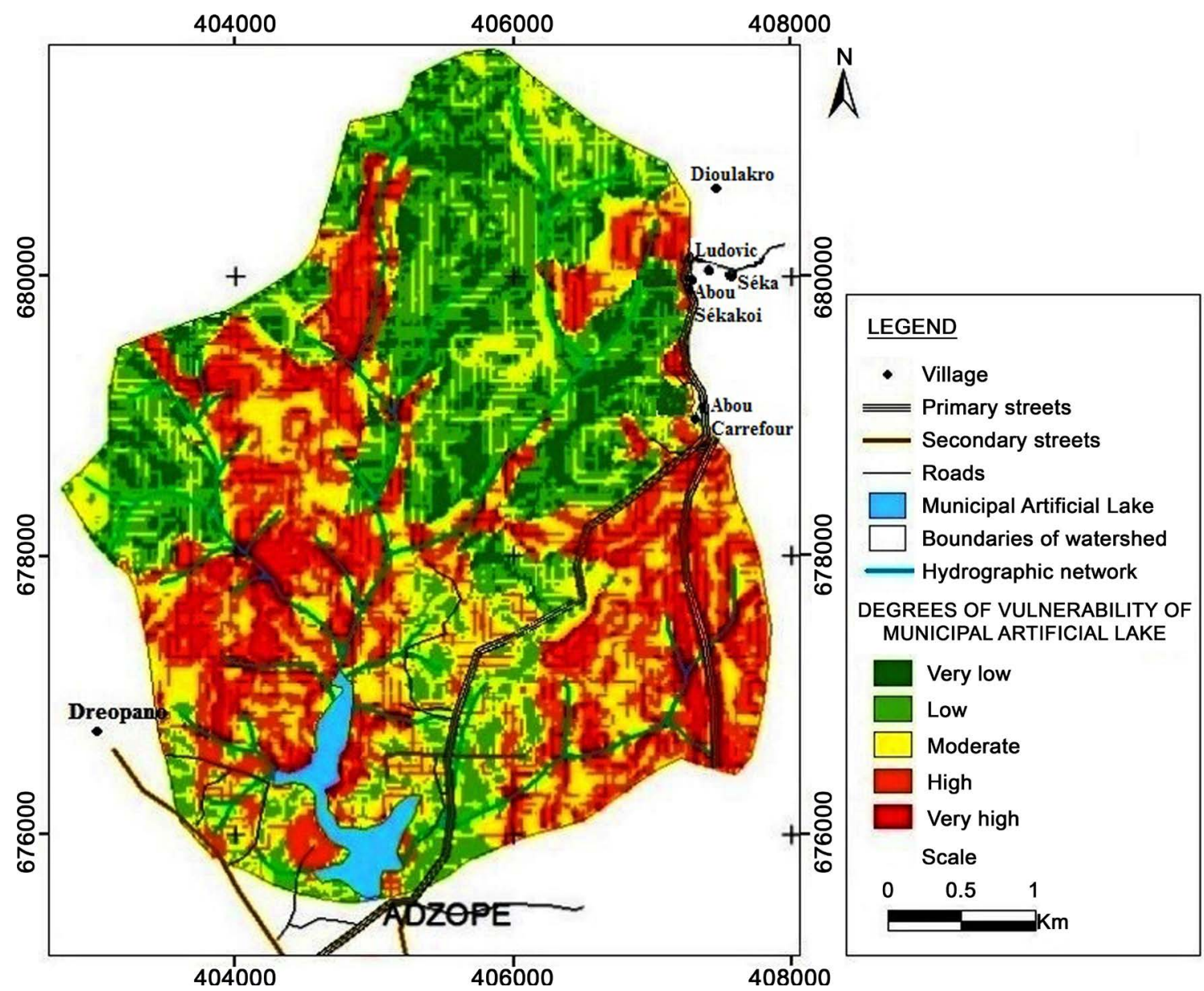

Figure 5. Vulnerability to pollution map of Municipal Artificial Lake of the study area. 
in forest areas north of the watershed. This area is also characterized by low slopes $(0 \%-3 \%)$. These two factors favor water infiltration and make it difficult to transport pollutants to the reservoir. The low vulnerability class (23\%) is located in the northern and southern parts of the watershed. This vulnerability class in the southern of watershed is particularly due to the slope weakness and not to the presence of the forest as in the north. In addition, this area contains dwellings according to the land-use map. The moderate vulnerability class (32\%) is the most widespread (Figure 6). This vulnerability class spread over the entire study area may be the consequences of the average slopes (46\%). The high and very high vulnerability classes occupy $20 \%$ and $13 \%$ respectively. These two vulnerability classes are more pronounced in cultivation and fallow areas, which favor surface water pollution. In these cultivation areas, the drainage network density is important (greater than $1.33 \mathrm{~km} / \mathrm{km}^{2}$ ). In sum, high and very high vulnerability classes observed in these areas are due to the slope (greater than $7 \%)$, which would favor the runoff of pollutants from cultivated areas and habitats to the reservoir.

- Results of sensitivity analysis

The results of single-parameter sensitivity analysis test of the water reservoir vulnerability map to pollution reveals that there is a difference between the theoretical weights and the determined actual or effective weights (Table 8). These results show that the calculated effective weights for the parameters such as slope, soil type, runoff, and drainage network density are lower than their theoretical weights. On the contrary, only the land-use parameter has an effective weight $(28.42 \%)$ greater than its theoretical weight (27\%). Thus, land-use is

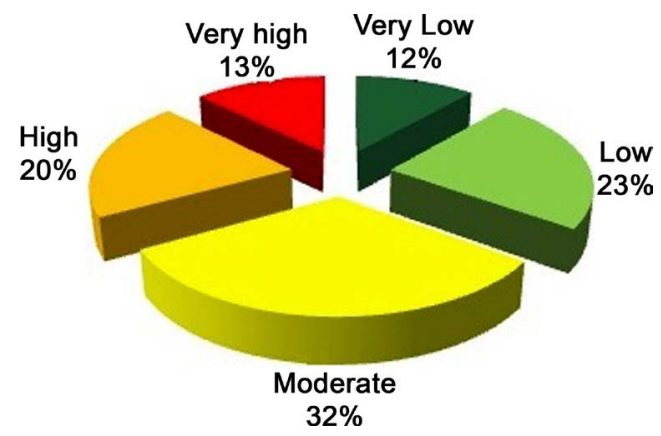

Figure 6. Percentages of vulnerability classes.

Table 8. Single-parameter sensitivity analysis test results.

\begin{tabular}{ccccc}
\hline \multirow{2}{*}{ Parameters } & Theoretical weights (\%) & \multicolumn{3}{c}{ Effective weights (\%) } \\
\cline { 3 - 5 } & & Wmin & Wmean & Wmax \\
\hline Slope (Sl) & 44 & 29.73 & 37.05 & 40.37 \\
Land-use (Lu) & 27 & 18.24 & 28.42 & 33.03 \\
Soil media (S) & 15 & 10.14 & 12.63 & 13.76 \\
Runoff (R) & 9 & 6.08 & 7.58 & 8.26 \\
Drainage network Density (D) & 5 & 3.38 & 4.21 & 4.59 \\
\hline
\end{tabular}


the parameter which has a more significantly influence in the assessment of the water reservoir vulnerability to pollution.

- Protection zones of the Municipal Artificial Lake

Figure 7 illustrates the boundaries of the different protection zones around surface water supply of study area. The immediate protection zone (Zone 1) includes very high, high, low and very low vulnerability classes that are contiguous to the water reservoir. Thus, the northern part of the immediate protection zone has greater width $(450 \mathrm{~m})$ because of the very high degree of vulnerability recorded in this area. In this area, although the slopes are small or medium, the drainage network density is high with the presence of cultivated land. To the south and west of the reservoir, the width of the immediate protection zone is $100 \mathrm{~m}$. This area corresponds to the high density of dwellings (habitations), where the school, treasury, and civil prison are located. In summary, the immediate protection zone around the water reservoir is defined from a radius which varies between 100 and $450 \mathrm{~m}$, with a total surface of $1.16 \mathrm{~km}^{2}$. The protection zone 2 contains some of the low, moderate and very high vulnerability classes. North of the water reservoir, the protection zone 2 reaches a width of $1 \mathrm{~km}$ and decreases towards near the watershed outlet. The eastern part

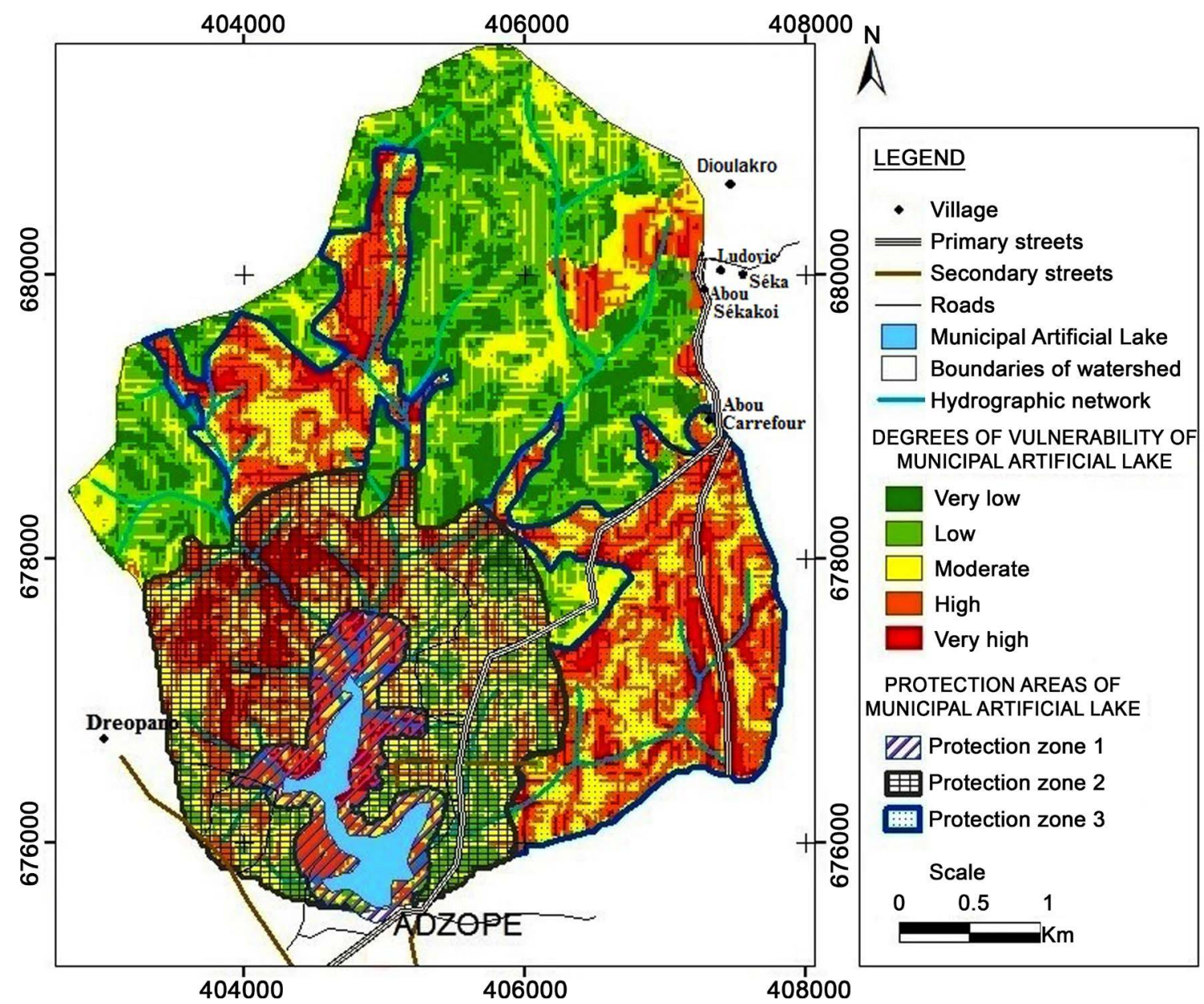

Figure 7. Protection zones map of the Municipal Artificial Lake of study area. 
of the water reservoir is less vulnerable than the western part due to the low slopes to the east and therefore the low drainage network density. The determined width of protection zone 2 varies between $350 \mathrm{~m}$ and $1 \mathrm{~km}$ from the boundaries of protection zone 1 with a surface of $5.38 \mathrm{~km}^{2}$. The protection zone 3 concerns the remainder of the highly vulnerable zones of the watershed bordering protection zone 2. It covers a surface of $5.69 \mathrm{~km}^{2}$. These areas are located to the west and north of the watershed. They correspond to strong slopes and crops areas.

\subsection{Discussion}

The geomatic approach based on the assessment of the Municipal Artificial Lake vulnerability to pollution allowed the delineation of three different protection zones around it. The established vulnerability map shows five (5) vulnerability classes (very low, low, moderate, high, and very high). This result is confirmed by the studies of [36] who showed that a vulnerability map to pollution gives an idea of the sensitive areas to which special attention must be given when planning of the territory. The protection zones were then determined by considering the spatial distribution of vulnerability classes on the watershed. Three protection zones have been delineated around the water reservoir. The protection zone 1 was delimited at distances between 100 and $450 \mathrm{~m}$ from the water reservoir, and covers a surface of $1.16 \mathrm{~km}^{2}$. This zone contains high and very high vulnerability area contiguous to the water reservoir. The low and very low vulnerability areas contiguous to the reservoir have a width of $100 \mathrm{~m}$ and the other areas vary up to $450 \mathrm{~m}$. The choice of the interval ( 100 to $450 \mathrm{~m}$ ) was prompted by:

- several authors such as [16] [34] [35] who recommended a distance of $100 \mathrm{~m}$ for delineating this protection zone;

- the existence of vulnerability classes of different degrees around the water reservoir;

- the access prohibition to the exploitation point and waters treatment facilities (or equipment) [35]; in fact, the distance of this zone must allow for appropriate intervention in the event of an accident linked to pollution of the water reservoir [19].

The protection zone 2 has a width of $350 \mathrm{~m}$ to $1 \mathrm{~km}$ from the limits of the protection zone 1; it covers a surface of $5.38 \mathrm{~km}^{2}$. It was delimited following the flow direction of surface waters in the watershed (from north to south towards water reservoir), and very high vulnerability areas. This distance is limited to 1 $\mathrm{km}$ from the water reservoir because, according to [19], at this distance, it is possible that a dissolved pollution directed towards the water reservoir can be intercepted or trapped due to the presence of suitable vegetation. The protection zone 3 concerns the remainder of more vulnerable areas of the watershed bordering the protection zone 2 . It covers a surface of $5.69 \mathrm{~km}^{2}$. The other areas of the watershed which are very low vulnerability were not taken into account. According to land use map, these areas correspond to forest areas. For [34], the 
protection zone 3 generally concerns the whole watershed draining the water reservoir. However, according to [35], it may correspond to a complementary area to the protection zone 2. [37] finds that the monitoring system establishment is preferable instead of a protection zone 3. In sum, the role of these protection zones is to ensure the surface water supply quality and, consequently, the population's health [19]. The results of the various protection zones obtained in this study, are substantially identical to those obtained by [11] [18] [19]. However, some difficulties were encountered during the implementation of the four steps of method used in this study. Concerning the choice of parameters, the difficulty lies in limiting their number to be taken account. According to [26] the choice of the parameters or criteria must be stopped at seven (7) at the level of hierarchical structure. Thus, the five parameters selected in this method were considered to be the most significant for assessing the surface water supply vulnerability and most used in studies carried out in Côte d'Ivoire by [19], elsewhere by [15] [16]. The establishment of the water reservoir vulnerability map in the study area may contain errors. Indeed, concerning the reclassification of land use thematic map, the same ratings were attributed to crops and fallows. However, a land left to rest, after several years, can reconstitute an open forest (woodland). In addition, parameters such as soil type $(\mathrm{S})$ and runoff $(\mathrm{R})$ didn't vary over extent of the study area. We could say that these parameters didn't have an important influence in the establishment of vulnerability map. The problem of sewage disposal and autonomous sanitation systems have not been integrated into the method used. The subjectivity of the assigned weights and ratings to the different parameters in Saaty's method (AHP) is also a difficulty [20]. The attributed values to the parameters sometimes tend to overestimate or underestimate the degree of vulnerability in the watershed. Indeed, to correct this subjectivity related to the assignment of ratings and weights to the parameters in assessing of vulnerability to pollution of water resource, the single-parameter sensitivity analysis, as applied by [38] [39] remains an effective solution. This analysis permits to adjust water resource vulnerability map previously established, from the actual or effective weights to obtain a modified vulnerability map of the water resource as demonstrated by several authors such as [40] [41]. These authors have also modified or adapted the ratings to the reality of the field so as to have a modified vulnerability map of the water resource more accurate and more reliable. In this study, by adapting this approach to the water reservoir vulnerability map according to the sensitivity analysis and certain specific conditions to the considered watershed can allow to adjust the limits of protection zones previously defined. The boundaries of protection zones vary from one author to another. This is certainly due to the variation in characteristics of the different study areas. It is a difficulty that has been circumvented or avoided in this study by imposing a distance interval for delineating protection zone 1. Finally, it is necessary to integrate in the method, the pollutants transit time and the relationship between the surface waters and the groundwater in the watershed. Thus, some protection zones are carried out on basis of the hydrological distance (length of the path 
followed by a drop water to water resource to be protected) [42] [43] However, others protection zones are carried out according to the water runoff transit time which seems to offer more precision because it integrates the slope, the terrain roughness and the rain intensity which provokes the flow [14]. But, it should be indicated that the transit time of a drop water to water reservoir or water resource to be protected, is not always comparable to the transit time of the pollutant. Indeed, some pollutant molecules with a high adsorption coefficient adhere or cling to the soil particles. This implies the choice of a transfer model in which the slope, soil media, runoff rate and especially land use revealed by the results of single-parameter sensitivity analysis test, are integrated. Then, GIS is a computerized solution for the delineation of protection zone as shown by [16]. It allows a wider and digital knowledge of water resources and their protection [14]. That is why, despite the various limitations listed in the method, the water reservoir vulnerability map is reliable. Consequently, the protection zones are acceptable and well adapted. Thus, the elaborated protection zones around $\mathrm{Mu}-$ nicipal Artificial Lake can be used for the easements establishment. In these areas, better practices concerning agricultural, domestic and industrial activities will be recommended to avoid the water reservoir pollution and continually ensure the supply of drinking water to the population of the study area.

\section{Conclusions}

Geographical Information Systems (GIS) methods have been used to determine three protection zones around the Municipal Artificial Lake in the study area. These protection zones were delineated after assessing the water reservoir vulnerability to pollution through the establishment of a vulnerability map. This map shows a dominance of moderate vulnerability (32\%) across the watershed and a high and very high vulnerability (20\% and $13 \%$ respectively) in the north, west and further east of the watershed. The vulnerability map, previous studies results and legislation in force have allowed producing the protection zones map of the water reservoir. The three (3) protection zones are:

- the immediate protection zone (zone 1) covering a surface of $1.16 \mathrm{~km}^{2}$, with a width between 100 and $450 \mathrm{~m}$ around the water reservoir;

- the protection zone 2 (Zone 2) covering a surface of $5.38 \mathrm{~km}^{2}$, with a width of $350 \mathrm{~m}$ to $1 \mathrm{~km}$ around protection zone 1 ;

- the protection zone 3 which is contiguous to protection zone 2 and covers a surface of $5.69 \mathrm{~km}^{2}$.

As in previous studies, this study has shown that geomatic approach from GIS is best indicated for assessing vulnerability to surface water supply pollution, but especially in delineating protection zones around of it. Pollution vulnerability and protection zones maps are innovative tools that will help decision-making in the sustainable preservation of the water quality of the Municipal Artificial Lake in Adzope region. Indeed, the protection zones established around this Municipal Artificial Lake must enable decision-makers to regulate domestic, industrial and agricultural activities and to monitor land-use planning or planning of ter- 
ritory in order to avoid polluting this vital resource for the population of Adzope region.

\section{Acknowledgements}

The authors acknowledge the Faculty of Earth and Mining Resources Sciences of Felix Houphouet-Boigny University for providing the available facilities to carry out this work. The author would like to thank Prof. Jourda Jean P. and Prof. Kouame Kan J. for providing constructive comments and suggestions which improved the manuscript. The author would also like to thank Dr. Djemin Edoukou J. for its contribution to the writing of this manuscript.

\section{References}

[1] Lallemand-Barres, A. and Roux, J.C. (1989) Guide méthodologique d'établissement des périmètres de protection des captages d'eau souterraine destinée à la consommation humaine. Collection: Manuels et Méthodes BRGM, No. 19, 224 p.

[2] Giraud, F. (1995) Actualisation du guide d'établissement des périmètres de protection des captages AEP: Cas des captages d'eau de surface. Rapport BRGM R 38853, $59 \mathrm{p}$.

[3] D.D.A.F. de la manche (2003) Les périmètres de protection des points d'eau destinée à l'alimentation en eau potable (A.E.P).

[4] Haudebert, L. and Saout, M.L. (1999) Protection des prises d'eau de surface, quelles stratégies? Guide méthodologique dubureau d'étude Saunier-techna, 59 p.

[5] BNETD (2008) Projet de délimitation des périmètres de protection autour des retenues d'eau de surface destinées àl'alimentation en eau potable des populations des villes de Daloa, Gagnoa et Adzopé; Proposition technique et finan-cière, $18 \mathrm{p}$.

[6] INS (2014) Recensement Général de la Population et de l'Habitat Institut National de la Statistique. Côte d'Ivoire, Abidjan, 26 p.

[7] Kouassi, B.A.T., Ouattara, A., Da, K.P. and Traoré, D. (2010) Zygophycees periphytiques de la retenue d'Adzope, Côted'Ivoire. Jounal of Applied Biosciences, 34, 2198-2207.

[8] Avenard, J.M. (1971) Aspect de la géomorphologie. Le milieu naturel de la Côte d'Ivoire. Mémoire ORSTOM, Paris, No. 50, 7-71.

[9] Soro, N. (1987) Contribution à l'étude géologique et hydrogéologique du Sud-Est de la Côte d'Ivoire, Bassin versant dela Mé. Thèse de doctorat, université scientifique, technologique et médicale de Grenoble, $229 \mathrm{p}$.

[10] Vernoux, J.F., Wuilleunier, A. and Dörfliger, N. (2007) Délimitation des bassins d'alimentation des captages et de leurvulnérabilité vis-à-vis des pollutions diffuses. Guide méthodologique, Rapport BRGM/RP-55874, 75 p.

[11] Eba, A.E.L., Kouamé, K.J., Deh, S.K., Balliet, R., Mahmoud, T., Anoh, K.A. and Jourda, J.P. (2016) Évaluation de la Vulnérabilité à la pollution d'une eau de surface destinée à l'adduction d'eau potable d'une métropole: Cas de la lagune Aghein à Abidjan (Sud de la Côte d'Ivoire). European Journal of Scientific Research, 12, 306-326. https://doi.org/10.19044/esj.2016.v12n36p306

[12] Rosi, S., Stamm, C. and Reichert, P. (2009) Modeling Potential Herbicide Loss to Surface Waters on the Swiss Plateau. Journal of Environmental Management, 91, 290-302. https://doi.org/10.1016/j.jenvman.2009.08.019

[13] USGS (2007) Données Topographiques. http://www.usgs.gov 
[14] Koffi, K.J.P., N’go, Y.A., Yeo, K.M., Koné, D. and Savané, I. (2014) Détermination des périmètres de protection de la la-gune Aghien par le calcul du temps de transfert de l'eau jusqu'à la lagune. Larhyss Journal, 19, 19-35.

http://lab.univ-biskra.dz/Larhyss/images/pdf/JOURNALN\%C2\%B019/2.Koffi_Kon an_et_al.pdf

[15] Schoen, R., Codvelle, A. and Ricard, J. (2001) Mapping the Hazard of Pollution of Surface and Groundwater by Plant Substances in the Midi-Pyrenees. Manual BRGM/RP-51456-FR, 46 p. (In French)

[16] El Garouani, A. and Merzouk, A. (2006) Délimitation des zones de protection autour de la retenue du barrage Hachef (Maroc) par télédétection et SIG. Revue des sciences de P eau, 19, 1-10. https://doi.org/10.7202/012170ar https://www.erudit.org/fr/revues/rseau/2006-v19-n1-rseau1034/012170ar.pdf

[17] Bezelgues, S., Des Garets, E., Mardhel, V. and Dörfliger, N. (2002) Cartographie de la vulnérabilité de Grand-Terre et de Marie-Galatie (Guadeloupe). Phase 1: Méthodologie de détermination de la vulnérabilité, $45 \mathrm{p}$. http://infoterre.brgm.fr/rapports/RP-51783-FR.pdf

[18] Anoh, K.A., Jourda, J.P., Kouame, K.J., Koua, T.J.J. and Lazar, G. (2012) Demarcation of Protection Perimeters for Surface Waters of Taabo (Ivory Coast) Watershed using GIS and Multi-Criteria Analysis. Environmental Engineering and Management Journal, 11, 2123-2131.

https://www.researchgate.net/profile/Gabriel_Lazar/publication/259641243_Demarcatio n_of_protection_perimeters_for_surface_waters_of_Taabo_Ivory_coast_watershed_usi ng_gis_and_multicriteria_analysis/links/0c960533f976d97684000000.pdf

[19] Eba, A.E.L., Jourda, J.P., Kouamé, K.J., Saley, M.B., Aké, G.E., Deh, S.K. and Anoh, K.A. (2013) Demarcation of Surface Water Protection Perimeters by Using GIS: Case of Gagnoa Reservoir in West Central of Côte d'Ivoire. International Journal of Scientific \& Engineering Research, 4, 1311-1320.

https://www.ijser.org/paper/Demarcation-of-Surface-Water-Protection-Perimetersby-Using-GIS-Case-of-Gagnoa.htm

[20] Deh, S.K., Kouamé, K.J., Saley, M.B., Tanoh, K.J.J., Anani, T.A., Signo, K.H., Jourda, J.P. and Biémi, J. (2012) Évaluationde la vulnérabilité spécifique aux nitrates (NO-3) des eaux souterraines du District d'Abidjan (Sud de la Côte d'Ivoire). International Journal of Biological and Chemical Sciences, 6, 1390-1408. https://doi.org/10.4314/ijbcs.v6i3.40 https://www.ajol.info/index.php/ijbcs/article/view/80926/71153

[21] Douay, D. and Lardieg, E. (2010) Délimitation des Aires d'Alimentation des captages prioritaires du bassin Adour Garonne. Méthodologie de cartographie de la vulnérabilité intrinsèque des captages d'eau superficielle, $28 \mathrm{p}$.

[22] Rasmussen, H. and Rouleau, A. (2003) Guide de détermination d'aires d'alimentation et de protection de captage d'eauxsouterraines. Centre d'étude sur les ressources minérales, Université de Québec à Chicoutimi; contrat du ministère del'environnement du Québec, 182 p.

http://www.mddep.gouv.qc.ca/eau/souterraines/alim-protec/outils.pdf

[23] Dabin, B. and Riou, G. (1960) Carte Pédologique de la Côte d'Ivoire au 1/2.000.000. Notice explicative, $39 \mathrm{p}$.

[24] Territ'eau. https://agro-transfert-bretagne.univ-rennes1.fr/Territ_Eau/CONNAISSANCES/Voi es_de_transfert/ruissellement.asp

[25] Carré, J., Marjolet, G., Burlot, T. and Rambert, B. (1997) Protection des prises d'eau de surface destinées à l'alimentationd'eau potable: L'exemple du breton TSM, $\mathrm{N}^{\circ} 3$, 
42-48.

[26] Saaty, T.L. (1980) The Analytic Hierarchy Process: Planning, Priority Setting, Resource Allocation. McGraw-Hill, New York, 19 p.

[27] Saaty, T.L. (1990) How to Make a Decision: The Analytic Hierarchy Process. European Journal of Operational Research, 48, 9-26. https://doi.org/10.1016/0377-2217(90)90057-I

[28] Dabral, S., Bhatt, B., Joshib, J.P. and Sharma, N. (2014) Groundwater Suitability Recharge Zones Modeling-A GIS Application. The International Archives of the Photogrammetry, Remote Sensing and Spatial Information Sciences, XL-8, 347-353.

[29] MAPAQ (1995) Guide d'application. Examen des projets de distribution au Québec d'eau embouteillée importée. Centrequébécois d'inspection des aliments et de santé animale, 29.

[30] Jourda, J.P., Kouassi, K.J., Adja, M.G., Deh, S.K., Anani, A.T., Effini, A.T. and Biémi, J. (2007) Évaluations du degré de protection des eaux souterraines: Vulnérabilité à la pollution de la nappe de Bonoua (Sud-Est de la Côte d'Ivoire) par la méthode DRASTIC. Acte de conférence Francophone ESRI 10 et 11 octobre-Versailles, $18 \mathrm{p}$.

[31] Napolitano, P. and Fabbri, A.G. (1996) Single-Parameter Sensitivity Analysis for Aquifer Vulnerability Assessment using DRASTIC and SINTACS. In: Kovar, K. and Nachtnebel, H.P., Eds., HydrolGis Application of Geographic Information Systems in Hydrology and Water Resources Management, IAHS Publication, Vol. 235, 559-566.

[32] Michèle, P., Anne-Sophie, M. and Dorner, S. (2011) Guide d'évaluation des sources d'approvisionnement en eau potable. Rapport, $230 \mathrm{p}$.

[33] Code de l'eau de la république de Côte d'Ivoire (1998) Loi n98-755 du 23 décembre 1998 Portant Code de l'Eau. Ré-publique de Côte d'Ivoire, 68 p.

[34] Achidi, J.B., Houngbedji, N., Sintondji, L.O. and Vilmus, T. (2010) Mise en place d'un dispositif de protection des zonesde captage d'eau potable. Guide méthodologique à l'usage des communes de la République du Bénin Ministère del'Énergie et de Direction Générale de l 'Eau, 30 p.

[35] Carré, J. (2005) Protection des prises d'eau de surface destinées à l'alimentation d'eau potable. $\mathrm{TSM} \mathrm{N}^{\circ} 4,27-34$.

[36] Jourda, J.P. (2005) Méthodologie d'application des techniques de Télédétection et des systèmes d'informations géographique à l'étude des aquifères fissurés d'Afrique de l'Ouest. Concept de l'hydrotechnique spatiale: Cas des zones tests de la Côte d'Ivoire. Thèse de Doctorat d'Etat, Université Félix Houphouët Boigny, 430 p.

[37] Fiquet, M. (1997) Périmètres de protection des captages destinés à l'alimentation en eau potable de la Martinique: Ele-ments nécessaires à leur définition. Rapport BRGM R 39731, 101 p. http://www.brgm.fr/Rapport?code=RR-39731-FR

[38] Djémin, É.J., Kouamé, K.J., Deh, K.S., Anani, T.A. and Jourda, J.P. (2016) Contribution of the Sensitivity Analysis in Groundwater Vulnerability Assessing using the DRASTIC Method: Application to Groundwater in Dabou Region (Southern of Côte d'Ivoire). Journal of Environmental Protection, 7, 129-143. https://doi.org/10.4236/jep.2016.71012

[39] Al-Abadi, A.M., Al-Shamma'a, A.M. and Aljabbari, M.H. (2017) A GIS-Based Drastic Model for Assessing Intrinsic Groundwater Vulnerability in Northeastern Missan Governorate, Southern Iraq. Applied Water Science, 7, 89-101. https://doi.org/10.1007/s13201-014-0221-7 
[40] Saidi, S., Bouri, S. and Ben-Dhia, H. (2011) Sensitivity Analysis in Groundwater Vulnerability Assessment Based on GIS in the Mahdia-Ksour Essaf Aquifer, Tunisia: A Validation Study. Hydrological Sciences Journal, 56, 288-304. https://doi.org/10.1080/02626667.2011.552886

[41] Neshat, A., Pradhan, B., Pirasteh, S. and Shafri, H.Z.M. (2014) Estimating Groundwater Vulnerability to Pollution using Amodified DRASTIC Model in the Kerman Agricultural Area, Iran. Environmental Earth Sciences, 71, 3119-3131. https://doi.org/10.1007/s12665-013-2690-7

[42] Rousseau, A.N., Maihot, A., Massicotte, A.S., Duchemin, M., Dupont, J. and Villeneuve, J.P. (1997) GIBSI: A Watershed-Based Software System for the Integrated Management of Surface Water Quality. Journal of Soil and Water Conservation, 25, 284-301.

[43] Melesse, A.M. and Graham, W.D. (2004) Tempête prédiction de ruissellement basé sur une méthode de temps de parcoursrépartis dans l'espace utilisant la télédétection et des SIG. Journal of American Water Resources Association, 8, 863-879. https://doi.org/10.1111/j.1752-1688.2004.tb01051.x 